\title{
Deus e o diabo na terra do sol Religião vivida, conflito e intolerância em filmes brasileiros
}

\author{
Júlio Cézar Adam*
}

\section{Resumo}

Este artigo pretende refletir a respeito das formas de conflito e intolerância na sociedade brasileira e apresentadas na cultura pop, mais especificamente, em filmes brasileiros, os quais tematizam a questão a partir de ou em relação com manifestações e expressões do campo religioso. Toma-se como princípio hermenêutico o conceito europeu de religião vivida (lived Religion ou gelebte Religion), um modo de perceber e analisar elementos, conteúdos e formas religiosas na esfera da cultura e da vida comum e cotidiana. Para tal, os filmes foram escolhidos levando em consideração nas narrativas e enredos a evidência da relação entre conflito, intolerância e a relação destes com a religião. Segundo este estudo, a partir dos filmes selecionados, podemos identificar três formas de conflito e intolerância relacionados à religião: a) o conflito sociopolítico com desdobramentos no campo religioso; b) o conflito e a intolerância dentro do próprio campo religioso; e, c) o conflito da falta de esperança e de perspectiva de vida. A análise dessa religião vivida deve servir também como subsídio para a reflexão da Teologia Prática neste contexto. Palavras-chave: Religião vivida. Cultura pop. Cinema brasileiro. Conflito. Intolerância.

\section{"God and the devil in the land of the sun" Lived religion, conflict and intolerance in brazilian films}

\begin{abstract}
This article aims to reflect on forms of conflict and intolerance in Brazilian society and presented in pop culture, more specifically, in Brazilian films, which thematize the issue from or in relation to manifestations and expressions of the religious field. The hermeneutical principle is the European concept of lived religion (gelebte Religion), a way of perceiving and analyzing elements, contents and religious forms in the sphere of culture and everyday life. For this, the films were chosen taking in consideration in the
\end{abstract}

* Possui graduação em teologia pela Escola Superior de Teologia EST (São Leopoldo/RS) (1996) e doutorado em teologia pela Universidade de Hamburgo, Alemanha (2004). Atua como professor na Faculdade EST (São Leopoldo/RS); e na Faculdade IENH. julioadam@est.edu.br 
narratives and entanglements the evidence of the relation between conflict, intolerance and the relation of these with the religion. According to this study, from the selected films, we can identify three forms of conflict and intolerance related to religion: a) socio-political conflict with unfolding in the religious field; b) conflict and intolerance within the religious field itself; and, c) the conflict of lack of hope and perspective of life. The analysis of this lived religion should also serve as a support for the reflection of Practical Theology in this context.

Key-words: Religion lived. Pop culture. Brazilian cinema. Conflict. Intolerance.

\section{Dios y el diablo en la tierra del sol Religión vivida, conflito y intolerancia em películas brasileñas}

\section{Resumen}

Este artículo pretende reflexionar sobre formas de conflicto e intolerancia en la sociedad brasileña y presentados en la cultura pop, más específicamente, en películas brasileñas, las cuales tematizan la cuestión a partir del o en relación con manifestaciones y expresiones del campo religioso. Se toma como principio hermenéutico el concepto europeo de religión vivida, una forma de percibir y analizar elementos, contenidos y formas religiosas en la esfera de la cultura y de la vida común y cotidiana. Para ello, las películas fueron escogidas teniendo en cuenta en las narrativas y enredos la evidencia de la relación entre conflicto, intolerancia y la relación de éstos con la religión. Según este estudio, a partir de las películas seleccionadas, podemos identificar tres formas de conflicto e intolerancia relacionadas a la religión: a) el conflicto socio-político con desdoblamientos en el campo religioso; b) el conflicto y la intolerancia dentro del propio campo religioso; y c) el conflicto de la falta de esperanza y de perspectiva de vida. El análisis de esta religión vivida debe servir también como subsidio para la reflexión de la Teología Práctica en este contexto.

Palabras clave: Religión vivida. Cultura pop. Cine brasileño. Conflicto. Intolerancia.

\section{Introdução}

Este estudo pretende refletir a respeito de possíveis formas de conflito e intolerância presentes no contexto brasileiro e como estas se veem refletidas e expressas em manifestações e formas religiosas. A análise será feita tomando por base a cultura pop, mais especificamente em exemplos exibidos em filmes brasileiros que expõem algum tipo de conflito e intolerância em nível pessoal, grupal ou social, relacionando-os com a religião. Este foi o critério para a escolha dos filmes: filmes brasileiros, onde formas de conflito e intolerância pessoal, grupal ou social faziam-se presentes; direta ou indiretamente relacionadas a alguma expressão de cunho religioso.

Não se trata de um estudo totalizante e conclusivo sobre intolerância e conflito na sociedade brasileira e seus reflexos no campo religioso. Busca-se, 
sim, apenas levantar indícios dessa relação e refletir a respeito. Ou seja, não se pretende fazer uma reflexão sistemática acerca do contexto de conflito social e político, nem tampouco acerca da complexa dinâmica religiosa no contexto brasileiro. Pretende-se, sim, observar como essas relações se dão nos enredos dos próprios filmes e, a partir desse olhar, traçar algumas conclusões para a pesquisa teológica, especialmente a Teologia Prática. Tampouco se trata de um estudo com pretensões de análise ampla e profunda da cinematografia brasileira. Certamente, nessa relação, outros filmes ficaram de fora. Opta-se aqui por alguns filmes onde há a relação entre conflito, intolerância e religião. Ao todo, a partir desse critério, seis filmes foram selecionados: Deus e o Diabo na Terra do Sol, Batismo de Sangue, O Pagador de Promessa, O Auto da Compadecida, Ó pai ó e Linha de passe.

Esse método de análise e reflexão tem como fundamento o princípio hermenêutico da religião vivida, que, por sua vez, tem por base os autores europeus Failing/Heimbrock, Gräb, Ganzevoort e Gutmann, os quais o utilizam como uma hermenêutica aplicada à Teologia Prática. Segundo esses autores, religião vivida é uma forma de olhar e de perceber a religião e a teologia não em primeiro lugar a partir de suas concepções teóricas, sociológicas, dogmáticas e a partir da tradição da Igreja, mas, sim, a partir daquilo que a cultura e que as pessoas fazem e dizem ser religião e o religioso, como uma nova maneira de se fazer Teologia Prática, como apontam Ganzevoort e Roeland:

Os conceitos de prática e religião vivida focam naquilo que o povo faz em vez de na religião "oficial", seus recursos sagrados, suas instituições e suas doutrinas. Assim, a Teologia Prática tem muito em comum com áreas como antropologia, sociologia e ciências da comunicação, e sua conhecida "virada prática": o afastamento dos institutos e dos textos (culturais) para as práticas sociais e culturais cotidianas das pessoas comuns (GANZEVOORT; ROELAND, 2014, p. 93).

Importante observar que religião vivida não tem a ver apenas como forma implícita da religião e do religioso, mas também com formas explícitas, ou seja, avaliando a teologia que as pessoas fazem, a maneira como elas interpretam sua espiritualidade e vivência de igreja. Em ambos os casos, portanto, a tradição e as matrizes religiosas são importantes, pois é a partir delas que a religião vivida pode ser entendida e posta em diálogo com a própria Teologia, ou seja, "as ações e os significados operantes nas maneiras em que as pessoas vivem, interagem e se relacionam com o divino" (GANZEVOORT, 2009). 
Portanto, uma hermenêutica da religião vivida, neste estudo, nada mais é do que uma forma de perceber e ler elementos, conteúdos e formas religiosas na esfera da cultura pop e da vida cotidiana e comum, ou seja, fora da instituição religiosa, fora do culto, fora da própria esfera sagrada e fora da religião dogmática, analisando sua presença em filmes brasileiros. No caso dos filmes selecionados analisa-se a religião vivida apenas na maneira como ela é vivenciada, divulgada e crida dentro do enredo do filme, na relação com conflitos e intolerâncias. Outras formas de abordagem, por exemplo, a maneira como o público assiste, vivencia e compreende essa religião expressa na obra cinematográfica e como este a relaciona com a sua crença e religiosidade, ou seja, a maneira como a pessoa olha e é olhada pela religião expressa no filme, abordagem bastante utilizada nos estudos da religião vivida, não será aqui abordada.

Procura-se, portanto, refletir sobre como a religião vivida expressa nos filmes selecionados dialoga, expressa, reforça ou se opõe a formas de conflito e intolerância pessoal, grupal ou social. O número de filmes onde essa relação se faz presente (cinco) evidencia o quanto há elementos de religião presentes nos filmes brasileiros e, também, o quanto a religião, especialmente a religião vivida, está relacionada a conflitos sociais ou de ordem religiosa, cultural ou humana. Analisou-se de forma especial essa relação nos meandros da narrativa de cada filme, como espaço peculiar onde se mostra aquilo que mais especificamente constitui uma cultura e uma religião, algo que, como aponta Roberto DaMatta

[...] discutir as peculiaridades de nossa sociedade é estudar também essas zonas de encontro e mediação, essas praças e adros dados pelos carnavais, pelas procissões e pelas malandragens, zonas onde o tempo fica suspenso e uma nova rotina deve ser repetida ou inovada, onde os problemas são esquecidos ou enfrentados; pois aqui - suspensos entre a rotina automática e a festa que reconstrói o mundo - tocamos o reino da liberdade e do essencialmente humano. É nessas regiões que renasce o poder do sistema, mas é também aqui que se pode forjar a esperança de ver o mundo de cabeça para baixo (DAMATTA, 1997, p. 18).

A hermenêutica da religião vivida leva-nos também a refletir sobre o cinema em si, como um espaço de expressão da religião e do religioso a partir daquilo que a própria obra cinematográfica e a cultura pop exibem. Entende-se, portanto, aqui, o cinema como ponto de encontro de olhares e 
espaço onde a religião vivida se apresenta de forma diferente da religião institucional e das teologias oficiais, como uma fonte instigante para a própria reflexão teológica. Segundo Santos, "o cinema deveria interessar à teologia por uma razão muito simples: não houve, desde o último século, outra maneira mais eficaz de produzir e contar histórias como o cinema" (SANTOS, 2014, 242). Santos fala de pelo menos duas eficácias do cinema do ponto de vista teológico. A primeira eficácia tem clara relação ao mito, ao conteúdo e às linguagens que compõem o cinema, ou seja, pelas histórias contadas, os temas, os gêneros, personagens e artistas, mitologias. Temos, portanto, neste estudo a partir do cinema, não apenas a apresentação de elementos e formas religiosos da realidade cotidiana e suas mediações, mas também, a possibilidade de refletir como no âmbito da religião vivida se dá a relação com conflitos e intolerâncias.

A segunda eficácia está relacionada à dinâmica que ocorre no cinema, ao rito, pelo qual se cria uma mediação entre a pessoa e o próprio filme por meio do olhar, algo que, como já vimos, também está relacionado aos estudos da chamada religião vivida. De acordo com o autor, considerando que uma das marcas da modernidade é a ação do sujeito sobre a realidade e a natureza, no sentido de olhá-la e dominá-la, com o cinema surge uma nova relação, por intermédio da qual o sujeito é dominado por aquilo que olha: "um filme é sempre um ponto de vista e de escuta em plena atividade" (SANTOS, 2014, p. 249), que alcança a subjetividade de quem assiste, sofre e participa de um filme. Essa eficácia ritual, por si só, aproxima-se também muito da própria experiência religiosa. Ou seja, o cinema causa algo na pessoa que o assiste, colocando-a em estreita sintonia com a reflexão a respeito da própria vida e acerca da realidade de conflitos e intolerâncias em que estamos inseridos, por um lado, e, por outro, como essa realidade está relacionada com a religião individual e coletiva, algo ainda a ser explorado.

\section{Contexto cultural e religioso brasileiro: um contexto reli- gioso de conflito e intolerância}

No senso comum brasileiro, fala-se que a sociedade brasileira é pacífica - "aqui não temos guerra" é uma constatação comum de se ouvir - e que a sociedade é tolerante diante das diferenças religiosas - Deus, além de ser brasileiro, é o mesmo Deus, não importando qual seja a confissão religiosa. Essa narrativa do pacifismo social e da tolerância religiosa se esvai frente à menor observação da realidade cotidiana ou uma rápida análise de contexto. 
A sociedade brasileira é uma sociedade marcada pelo conflito social e por disputas no campo religioso, mesmo que estas, muitas vezes, sejam veladas e discretas (CUNHA, 2016; 2016b).

É muito difícil em um curto espaço dizer o que é o Brasil (DAMATTA, 2004; RIBEIRO, 2000), mas certamente a mais simples tentativa de definição irá esbarrar nessa certa contradição entre imaginários, idealizações e realidades, nos contrastes e contradições existentes e na presença permanente de diferentes formas de conflitos. Talvez três características sejam importantes realçar como pano de fundo deste estudo. A primeira delas tem a ver com a miscigenação do povo brasileiro. Segundo José Honório Rodrigues:

[...] somos uma república mestiça étnica e culturalmente. Não somos europeus nem latino-americanos. Somos tupinizados, africanizados, orientalizados e ocidentalizados. A síntese de tantas antíteses é o produto singular e original que é o Brasil atual (BOFF, 2000, 19).

A segunda característica é a profunda desigualdade social, crônica, perpetuada ao longo dos séculos, marcada, sobretudo, por uma dificuldade e uma recusa em ver a própria desigualdade (ADAM, 2005):

Somos uma sociedade de história lenta, porque os momentos estão descompassados, numa espécie de esquizofrenia histórica. Se houvesse entre nós uma consciência política do desenvolvimento desigual e do descompasso entre as instâncias desencontradas do processo histórico, nosso ritmo de mudança e atualização dessas instâncias seria mais rápido, as desigualdades superadas mais depressa e, provavelmente, com mais justiça social (MARTINS, 2012, 294).

Uma última característica, decorrente das duas primeiras, é o permanente estado de conflito, de crise e de violência de uma sociedade organizada em torno de interesses individuais e grupais (MARTINS, 2012, 298). Se tomarmos apenas os homicídios dolosos (com intenção de matar), sem considerar a violência doméstica, física e sexual, contra menores, roubos e furtos, violência no trânsito, 143 pessoas foram mortas diariamente, somando algo por volta de 52 mil pessoas no ano de $2014 .^{1}$

Quanto à religião, podemos dizer que há um espelhamento das três características já arroladas. Religião no Brasil tem essencial e constitutiva-

Brasil teve em média 143 assassinatos por dia em 2014. Disponível em: http://www.mapadaviolencia.org.br/mapa2016_armas.php Acesso em 10/05/2017. 
mente a ver com diversidades e miscigenação (sincretismo, hibridismo), a desigualdades (religiões hegemônicas versus religiões reprimidas) e o conflito (fundamentalismo e relativismo) (CUNHA, 2016). Os embates com a religião ou com desdobramentos no campo religioso são algo que está presente e de forma permanente nesse contexto. Sabe-se que religião fazia parte da vida cotidiana dos povos originários. A invasão portuguesa, em 1500, é assinalada por uma missa campal, logo, do desembarque dos ibero-europeus e o que se segue a essa missa na relação com as religiões originárias, com as religiões dos africanos trazidos como escravos, as religiões vindas com os demais imigrantes, será um grande processo de disputas, sincretismos, e mobilidade religiosa. ${ }^{2}$

$\mathrm{Na}$ questão religiosa, é importante analisar quais são as compreensões de religião e do religioso presentes nesse contexto conflitivo. Adilson Schultz propõe uma forma de pensar a estrutura teológica a partir do imaginário religioso brasileiro, a qual ele define como uma nebulosa. Ele usa o termo "nebulosa" por entender que não há uma base sobre a qual se constroem as religiões ou a matriz religiosa brasileira, mas sim, algo, significações, que transitam entre as religiões e suas matrizes (SCHULTZ, 2008, 31). De acordo com o autor, no mínimo três referências abastecem essa nebulosa:

A matriz religiosa brasileira tem como principais referências as significações religiosas oriundas do catolicismo, das religiões afro-brasileiras e do espiritismo - além das significações indígenas naquilo que elas têm de influência sobre umbanda, espiritismo e candomblé (SCHULTZ, 2008, 28).

Segundo ele, essa nebulosa, forjada num lento processo histórico, paira sobre o país e não cessa de se repetir num processo contínuo de ressignificação de valores e princípios, algo que faz muito sentido para a reflexão acerca das diferentes formas e conteúdos da religião vivida que aqui tomamos como hermenêutica. O autor complementa sua ideia pegando de G. Deleuze a teoria rizomática. Diferente de raízes, que estão conectadas a um mesmo ponto, "a lógica do rizoma opera por rupturas e interconexões ao mesmo tempo" (SCHULTZ, 2008, 33). Nessa ideia da nebulosa e do rizoma, o autor trabalha algumas de suas características. A crença e a presença de Deus em meio à vida são uma dessas características. O mundo invisível, de Deus, está

2 Interessante para entender essa dinâmica das religiões no Brasil é o filme Santo Forte, de Eduardo Coutinho, 1999 (Santo Forte, Eduardo Coutinho, BRA, 1999). 
imbricado no mundo visível, das pessoas. Do mesmo modo, o diabo e o mal compõem esse cenário. Além de Deus e do diabo e sua presença em meio à vida cotidiana, outras forças e entidades irão compor a nebulosa, como a crença em espíritos, a prática de sacrifícios, a comunicação com o mundo do além, as formas de louvor e êxtase nos cultos, as incorporações, as expectativas pela vida eterna, a teologia da prosperidade, entre tantas outras formas e expressões.

[...] uma nebulosa de ambiguidades e simultaneidades: tudo parece misturado; tudo tem mais de uma possibilidade; o bem e o mal não são facilmente discerníveis; Deus e o mal são transcendentes e, ao mesmo tempo, imanentes; Deus está na Igreja, mas também está no terreiro, a fé é confessada em alta voz, mas vive de significações subterrâneas, não reveladas (SCHULTZ, 2008, 35).

Todos esses elementos vão compor o que podemos chamar de religião vivida presente nos filmes a serem analisados a seguir, e essa religião vivida está totalmente imbricada com os conflitos, intolerâncias e violências que compõem o cenário da vida real, assim podemos preliminarmente afirmar.

\section{Religião vivida nos filmes: uma análise}

Neste ponto, pretende-se analisar formas e exemplos de conflito e intolerância relacionados a elementos, formas e expressões religiosas, presentes em alguns filmes brasileiros. Analisa-se aqui a religião e o religioso como uma forma de religião vivida, uma compreensão e uma vivência da religião que ultrapassam as fronteiras da religião institucional e dogmática. Em alguns casos, o conflito se dá exatamente porque a maneira como a religião é vivida contrasta e atrita com pressupostos da religião oficial ou do contexto sociopolítico ou ambos.

A partir desses materiais cinematográficos pertencentes à cultura pop brasileira, pode-se dizer que há, fundamentalmente, três tipos de conflito sociorreligioso: a) o conflito sociopolítico com desdobramentos no campo religioso; b) o conflito e a intolerância dentro do próprio campo religioso; e, c) o conflito da falta de esperança e de perspectiva de vida.

\section{a. Deus e o Diabo na Terra do Sol e Batismo de Sangue: conflito sociopolítico com desdobramentos no campo religioso}

Nesses dois exemplos têm-se já no próprio título dos filmes algo religioso e algo de conflitivo: Deus e o diabo e batismo de sangue. O filme 
Deus e o Diabo na Terra do Sol (Glauber Rocha, BRA, 1964), aborda um tipo específico de conflito social no nordeste brasileiro. O conflito se dá entre sertanejos, pessoas pobres, destituídas de qualquer poder e de recursos mínimos para a manutenção de suas vidas, agravado pela situação permanente de seca e estiagem, e aqueles que detêm os recursos e o poder, o que na história do país se constitui como coronelismo (ADAM, 2005). O elemento religioso está presente de forma muito explícita tanto do lado dos despossuídos quanto do lado do coronelismo, representado principalmente pela instituição religiosa hegemônica (CUNHA, 2016), no caso a Igreja Católica.

O enredo do filme conta a história de Manoel (Geraldo Del Rey) e sua mulher Rosa (Yoná Magalhães). As cenas iniciais do filme indicam a profunda miséria e carência, cena típica do sertão nordestino, mostrando a vegetação seca e a morte do gado, o trabalho árduo do casal para garantir a pouca comida que há. Também no começo do filme mostra-se o incipiente movimento messiânico da região, em torno ao beato Sebastião, recrutando pessoas miseráveis com a promessa do retorno do rei português Dom Sebastião, algo que impressiona Manuel. O movimento messiânico Sebastianismo - de fato ocorreu no sertão de Pernambuco, no século XIX (BALTAZAR B. JÚNIOR; BARREIRA, 2013). Miséria e religião dividem a cena, por assim dizer.

Manuel é um vaqueiro e acaba de levar o gado do coronel Moraes (Milton Roda) para a cidade, tendo como combinação a partilha dos lucros obtidos com a venda do gado. O vaqueiro pretende usar o recurso obtido para comprar um pedaço de terra. Quando leva o gado para a cidade, alguns animais morrem no percurso. Chegado o momento da partilha, o coronel diz que não vai dar ao vaqueiro a sua parte nos lucros porque o gado que morreu no percurso seria a parte correspondente a Manuel, ao passo que a parte que chegou viva era sua. Manoel, profundamente irritado com a injustiça e o abuso do coronel, mata-o com um facão e foge para casa. Sem recursos e, agora, perseguido, o casal se junta aos seguidores do beato Sebastião (Lídio Silva), que promete o fim do sofrimento por meio do cumprimento da profecia de que o sertão irá virar mar e que todos os seguidores viverão em uma ilha de fartura e abundância, com o retorno de Dom Sebastião, rei de Portugal.

O movimento reúne milhares de sertanejos paupérrimos sobre uma montanha, na pequena capela de Pedra Bonita, à espera que chova ouro e que a profecia se cumpra. Além de saques e pilhagens feitos pelos seguidores do movimento na redondeza, sacrifícios precisam ser realizados para que a 
promessa se cumpra. Manoel sobe de joelhos a longa escadaria da igreja com uma enorme pedra sobre a cabeça. Como a promessa não se cumpre, o beato Sebastião pede que uma criança - sangue inocente - seja sacrificada no altar da igreja e que Rosa, que é contrária ao movimento, seja morta. Segundo o beato, ela estaria possuída por demônios. Rosa acaba matando o beato a facadas no interior do santuário.

Simultaneamente, distante da Pedra Bonita, a vida no vilarejo se vê ameaçada pelo movimento sebastianista. O padre lamenta o abandono dos fiéis da missa regular, além de condenar o movimento como fanatismo religioso. Apoiado pela elite local, os coronéis latifundiários, o próprio padre paga Antônio das Mortes (Maurício do Valle), um matador de aluguel, para exterminar os seguidores do beato. Assim, um verdadeiro massacre é perpetrado. Todos os seguidores do movimento são assassinados.

Manoel e Rosa escapam do massacre e se juntam ao cangaço - movimento de bandidos-justiceiros do sertão brasileiro. O pequeno grupo de cangaceiros com requintes de crueldade ataca os vilarejos da região, roubando tudo que é possível, violentando e matando sem piedade, em nome de uma nova ordem social a partir da justiça feita pelas próprias mãos. Ou seja, Manoel é alguém que está em busca de uma vida digna. Primeiramente, como vaqueiro, valendo-se do próprio sistema social injusto, depois como penitente por meio da fé e da esperança no cumprimento de uma profecia, por último, quando os dois outros mecanismos falharam, ele se torna cangaceiro, fazendo justiça deliberadamente com as próprias mãos, sendo, ele mesmo um pouco de Deus e um pouco de diabo em meio às agruras da vida debaixo do sol violento do sertão. Nos três movimentos, há crença, conflito e violência.

Fica muito claro nesse exemplo o conflito endêmico brasileiro: o conflito social, entre os destituídos de todo e qualquer recurso para viver de forma digna e a concentração de poder nas mãos de alguns, e os mecanismos criados por estes para preservar seus bens e evitar que os destituídos tenham acesso. ${ }^{3}$ A religião acompanha o conflito. Para os destituídos, a religião acaba servindo como subterfúgio como o messianismo sebastianista. A religião buscada está fora dos limites do institucional e é uma proposta radical e violenta. A religião institucional e hegemônica sustenta o status quo.

3 Atualmente, essa discussão ganha as telas em produções cinematográficas que abordam o acesso de jovens à universidade através da lei de cotas para pessoas de baixa renda, negras e indígenas e o conflito gerado com isso. Um bom exemplo é o filme Que horas ela volta? (Anna Muylaert, BRA, 2015). 
Interessante no filme é que, após o fim violento do movimento messiânico, Manoel encontra abrigo no cangaço. Cangaço invade e destrói violentamente uma festa de casamento, atacando claramente tanto a religião oficial quanto a cultura social hegemônica. Há, assim, uma constelação de conflito social, poder político e religioso, fanatismo, messianismo e violência.

O filme Batismo de Sangue (Helvécio Ratton, BRA, 2007) é ancorado na obra homônima (FREI BETTO, 1983), dirigido por Helvécio Ratton, em 2007. Temos aqui um claro conflito ideológico envolvendo religiosos católicos identificados com a Teologia da Libertação e as forças repressivas da ditadura militar. Em São Paulo, no final da década de 60, o convento dos frades dominicanos é espaço de resistência contra a ditadura militar. Movidos por ideais cristãos sistematizados na então nascente Teologia da Libertação, os frades, entre eles Frei Tito (Caio Blat) e Frei Betto (Daniel de Oliveira), apoiam política e logisticamente o grupo de guerrilheiro Ação Libertadora Nacional, liderado por Carlos Marighella (Marku Ribas). Os frades acabam sendo presos e torturados por policiais do DOPS paulista, (Departamento de Ordem Política e Social, da ditadura militar) obrigados a denunciar o movimento de guerrilha. Frei Tito é exilado na França, não conseguindo superar as sequelas psicológicas, vindo mais tarde a suicidar-se.

Ao lado das cenas chocantes de tortura, o filme é marcado por cenas da devoção religiosa dos frades, como a cena em que realizam uma eucaristia na prisão, utilizando suco de uva solúvel e bolachas, partilhando os elementos tanto com opositores políticos quanto com os policiais que os torturavam. Frei Tito inicia a reflexão antes da oração eucarística recitando do profeta Isaías o versículo que diz: "julgará os fracos com equidade, fará justiça aos pobres da terra, ferirá o homem impetuoso com uma sentença de sua boca, e com o sopro dos seus lábios fará morrer o ímpio" (Isaías 11.4). Frei Betto continua, dizendo: "Não há conciliação possível entre opressores e oprimidos. Do lado de dentro dessas grades encontram-se comunistas e cristãos. Foi o amor por nosso povo e luta por justiça que nos aproximou e nos uniu. Um dia, todos viverão como irmãos, em torno do mesmo Pai. Haverá igual partilha de comida e de bebida, como aqui, nesta mesa eucarística".

É muito explícito no filme uma concepção religiosa e teológica diferente das encontradas no filme anterior: a teologia crítica, de cunho social e político. Não temos aqui a concepção do catolicismo popular ou de outra religiosidade, mas uma posição nova, racional e engajada, disposta não só a transformar a própria compreensão teológica, mas, principalmente, o contexto 
social, por meio da luta contra a ditadura, como aglutinadora das forças de opressão e dominação política presentes nesse período da história brasileira. Também aqui temos, portanto, poder político, conflito, religião institucional e fé engajada em jogo.

Nos dois filmes, fica muito evidente o conflito social e político presente no contexto brasileiro, assim como evidencia-se o papel da religião. Em comparação com o filme anterior, temos aqui também a religião permeando o conflito político. O que leva os frades à tortura e à prisão é a convicção religiosa, a resistência ao regime ditatorial com base na fé cristã, como um verdadeiro sacrifício, um batismo de sangue. Também aqui é uma compreensão da religião, no caso a teologia crítica de cunho político, que entra em atrito com o sistema hegemônico e absoluto da ditadura.

\section{b. O Pagador de Promessa, O Auto da Compadecida e Ó pai ó: o conflito interno religioso}

Esses três filmes caracterizam outro tipo de conflito e intolerância presentes no contexto brasileiro. O conflito e a intolerância internos no próprio campo religioso. As disputas aqui se dão entre o catolicismo popular, o sincretismo religioso e as religiões de matriz africana, por um lado, e a igreja católica oficial romanizada (STEIL, 1996) ou a igreja evangélica pentecostal, por outro.

O Pagador de Promessas (Anselmo Duarte, BRA, 1962) é um filme de 1962, dirigido por Anselmo Duarte, ancorado na peça teatral de Dias Gomes. O enredo gira em torno do sincretismo religioso, como parte do catolicismo popular, e as religiões de matriz africana, e a intolerância por parte do catolicismo institucional.

O filme inicia com os atabaques e danças de um culto do candomblé, dando assim o tom do conflito. O filme apresenta a história do pagador de promessas, chamado Zé do Burro (Leonardo Villar), homem humilde, ingênuo e bondoso, que enfrenta a intransigência e o rigor doutrinário da instituição igreja ao tentar cumprir a promessa feita a Santa Bárbara (sincretizada em Iansã, no candomblé). A promessa consiste em carregar uma pesada cruz, do tamanho da cruz de Cristo, por sete léguas, até o santuário da santa, a Igreja de Santa Bárbara, na cidade de Salvador, capital do Estado da Bahia, e dividir seu pequeno pedaço de terra, no interior, com os vizinhos mais pobres. Seu melhor amigo é um burro, chamado Nicolau. Quando este é ferido por um raio e adoece em decorrência do 
ferimento, Zé do Burro faz a promessa a Santa Bárbara (santa protetora nas tempestades), em um terreiro de candomblé, à orixá Iansã. Assim que o burro Nicolau se recupera, Zé do Burro, acompanhado de sua mulher Rosa (Glória Menezes), dá início à sua jornada.

O conflito se dá com o padre local, padre Olavo (Dionísio Azevedo), que representa a autoridade da religião oficial e hegemônica. Após o padre ouvir que a promessa foi feita para salvar um burro, o Nicolau, e que a promessa foi realizada no terreiro de candomblé, para Iansã, paralelo de Santa Bárbara na religiosidade afro-brasileira, e que para Zé do Burro não há problema algum na sua concepção sincrética de religião, proíbe Zé do Burro de entrar com a cruz na igreja e, assim, cumprir sua promessa. Além disso, a partilha de terras feita por Zé do Burro dá margem a interpretações pela mídia sensacionalista de que ele seria comunista. Zé e Rosa são assim barrados nas escadarias da igreja de Santa Bárbara, local onde irá se desenrolar praticamente todo o filme.

As pessoas tentam se aproveitar da inocência e bondade de Zé do Burro. Prevalecem-se do conflito criado: Os praticantes de candomblé querem usá-lo como líder contra a discriminação que sofrem por parte da igreja, eles têm acesso apenas aos degraus da igreja; os jornais sensacionalistas e os políticos transformam sua promessa de dar a terra aos pobres em grito pela reforma agrária; um escritor de livros pretende ganhar dinheiro escrevendo a história do pagador de promessas; a mulher, Rosa, cansada de esperar, o trai com o cafetão (Geraldo Del Rey) da redondeza.

Zé insiste em entrar na igreja e recebe o apoio da população pobre, que acredita que ele tem o direito de pagar sua promessa, criando, assim, uma situação de conflito com o padre. Pessoas doentes e pobres vêm até Zé pedindo por cura. Diante do conflito instalado, a polícia é chamada para prevenir a entrada de Zé na igreja, e ele acaba morto em um confronto violento entre policiais e manifestantes ao seu favor. $\mathrm{Na}$ última cena do filme, os manifestantes pobres colocam o corpo morto de Zé em cima da cruz e entram à força na igreja. Finalmente, Zé do Burro cumpre sua promessa, mas para isso precisou pagar com a própria vida.

O conflito aqui é religioso, por excelência. A disputa se dá entre a religião oficial, preocupada com a reta doutrina e a manutenção da própria instituição, a religiosidade afro-brasileira, no caso o candomblé, mas também com a religiosidade popular de Zé do Burro, uma religiosidade mágica e pragmática, útil na cura dos animais, em sintonia com uma ética social de 
partilha e com uma teologia sincrética. Vemos nesse filme uma clara luta entre religião hegemônica e religiões reprimidas, algo que Cunha tem analisado em suas pesquisas sobre a intolerância religiosa presente no cotidiano brasileiro atual, uma intolerância por vezes discreta e velada, mas que tem tomado proporções maiores, como o caso de uma menina apedrejada após deixar o culto num terreiro de umbanda (CUNHA, 2016, 2016b).

O Auto da Compadecida (Guel Arraes, BRA, 1999) foi dirigido por Guel Arraes, lançado em 1999, também a partir de uma peça teatral, homônima, de Ariano Suassuna (Suassuna, 1955), combinando elementos de O Santo e a porca e Torturas de um coração, ambos do mesmo autor.

O enredo gira em torno de dois personagens principais: João Grilo (Matheus Nachtergale) e Chicó (Selton Mello). Ambos são pessoas pobres, como a maioria da população da região. Vivem de pequenos negócios, pequenos golpes, esperteza e malandragem. Praticamente, todo o filme se dá em torno dos pequenos golpes que João Grilo e Chicó organizam para se dar bem. A trama inicia quando Chicó e João Grilo tentam convencer o padre local (Rogério Cardoso) a benzer o cachorro doente de sua patroa, a mulher (Denise Fraga) do padeiro (Diogo Vilela). Como o padre se nega a benzer e o cachorro morre, o padeiro e sua esposa exigem que o padre faça o enterro do animal. João Grilo diz ao padre que o cachorro tinha um testamento e que lhe deixara dez contos de réis e três para o sacristão, caso encomendassem o cachorro em latim. Quando o bispo descobre, Grilo inventa que, na verdade, seis contos iriam para a arquidiocese e apenas quatro para a paróquia, para que o bispo não arrumasse problemas.

Assim continuam os dois personagens criando casos de trapaças e malandragens, até que os cangaceiros invadem o lugarejo. Ouvem-se tiros e uma gritaria do lado de fora, era o cangaceiro Severino (Marco Nanini). No conflito, ele mata o bispo (Lima Duarte), o padre, o sacristão, o padeiro e a mulher. $\mathrm{Na}$ hora de matar João Grilo, este lhe dá de presente uma gaita abençoada por Padrinho Padre Cícero (santo protetor e padroeiro do nordeste brasileiro) que teria o poder de ressuscitar as pessoas. Para o cangaceiro acreditar, João dá uma facada em Chicó, encenando sua morte usando uma bexiga com sangue. João Grilo toca a gaita enquanto o amigo levanta dançando no ritmo da música. Severino, então, ordena ao seu capanga que lhe dê um tiro e depois toque a gaita para que ele possa ir encontrar-se com Padre Cícero e depois voltar. O capanga obedece, atira, mas quando toca a gaita nada acontece. Com isso, o capanga mata João Grilo. 
No céu, todos se encontram para o julgamento dos mortos. O diabo (Luís Melo) e Jesus, negro, (Maurício Gonçalves) apresentam as acusações e defesas. João então chama Nossa Senhora (Fernanda Montenegro), a compadecida, para interceder por eles. É o que ela faz. Essa cena sobre a discussão a respeito da vida humana, o medo da morte, a culpa e o perdão, as referências à vida e morte de Jesus Cristo, é parte certamente de uma das peças teológicas mais belas e significativas de uma autêntica teologia brasileira, uma admirável amostra de religião vivida. O padre, o bispo, o sacristão, o padeiro e sua mulher são mandados para o purgatório. Severino e o seu capanga são absolvidos e enviados ao paraíso. João simplesmente retorna ao seu corpo. Quando retorna, vê Chicó o enterrando, levanta e dá um susto no amigo. Após conseguir fazer Chicó acreditar que está vivo, os dois se animam e fazem planos para o dinheiro do enterro. Até que Chicó lembra da promessa que fez a Nossa Senhora, que daria todo dinheiro caso João sobrevivesse. Depois da discussão sobre as possibilidades de como driblar a promessa feita, decidem entregar todo o dinheiro à igreja.

Vemos nessa comédia dramática muito da relação entre conflito e religião. O conflito, assim como no filme anterior, é entre a crença popular, recheada de subversões, subterfúgios e malandragens, a religião oficial do bispo e do padre, que também se deixa corromper, e a violência dos cangaceiros, os quais também têm fé. Estes, antes de matar cada um dos personagens, fazem um sinal da cruz e pedem a absolvição do padre. No céu, no julgamento, Jesus Cristo e Maria, a Compadecida, corroboram essa teologia vivida no cotidiano e na malandragem, uma teologia da justificação da vida e da luta humanas. Sob o protesto do diabo, todos acabam sendo absolvidos ou recebem nova chance. O conflito religioso e a violência encontram no céu, diante do próprio Cristo, a redenção.

Ó Pai ó (Monique Gardenberg, BRA, 2007) é um filme dirigido por Monique Gardenberg, ancorado na peça de Márcio Meirelles, lançado em 2007. O filme conta a história dos moradores de um animado cortiço no centro histórico da cidade de Salvador, no chamado Pelourinho. Toda a história se passa no último dia de carnaval, o que torna o filme praticamente uma folia de carnaval com muita dança, sexo, música e alegria. Até que Dona Joana (Luciana Souza), síndica do cortiço, uma evangélica pentecostal, incomodada com a farra e a festa dos moradores, decide acabar com a festa, fechando o registro de água do prédio. 
A falta d’água faz que o aspirante a cantor Roque (Lázaro Ramos); o motorista de táxi Reginaldo (Érico Brás) e sua esposa Maria (Valdinéia Soriano); o travesti Yolanda (Lyu Arisson), amante de Reginaldo; a jogadora de búzios Raimunda (Cássia Vale); a dona de bar Neuzão, lésbica (Tânia Tôko) e sua sensual sobrinha Rosa (Emanuelle Araújo); Carmen (Auristela Sá), que realiza abortos clandestinos e ao mesmo tempo mantém um pequeno orfanato em seu apartamento; Psilene (Dira Paes), irmã de Carmen que está fazendo uma visita após um período na Europa; e a baiana (Rejane Maia) vendedora de acarajé, de quem todos são fregueses; se confrontem e se solidarizem perante o problema.

Elementos religiosos do catolicismo popular e da religiosidade afro -brasileira não criam atrito entre si, nem com o clima de festa e excessos, tampouco com a sexualidade explícita, com a homossexualidade, com a prática do aborto, com o sincretismo, todas questões que encontram nas instituições religiosas, como a igreja, forte crítica e resistência. O único ponto de atrito é, de fato, com Dona Joana, que condena não só a festa de carnaval, mas sobretudo a religiosidade livre e dinâmica imiscuída na vida, no sexo e na festa dos personagens. Para ela, carnaval é oportunidade para o demônio possuir pessoas e afastá-las do verdadeiro caminho, a verdadeira fé, representada por sua igreja evangélica. Cortar a água é sua maneira de combater o mal em nome da fé.

Seus dois filhos pequenos enganam a mãe e também se divertem na festa de carnaval. Embaixo da escada do casarão escondem suas Bíblias antes de sair para a rua e caírem na folia. Um dos comerciantes do Pelourinho, incomodado com a presença dos chamados trombadinhas - crianças que vivem nas ruas e cometem pequenos furtos e delitos, algo que prejudica o comércio - encomenda a um policial, que lhe deve uma quantia em dinheiro, para dar um susto nas crianças. Para cumprir sua incumbência, o policial acaba matando os dois meninos de Dona Joana.

De grande relevância para este estudo é a cena, quase no final do filme, quando Dona Joana, preocupada com a demora de seus meninos para voltarem para casa, recorre a Dona Raimunda, a quem ela geralmente acusava de seguidora de Satã, pedindo que mostre no jogo de búzios o que ocorreu com os seus meninos. Raimunda, em transe, entra em colapso com a notícia que o jogo de búzios lhe dá: os meninos foram mortos. A cena final é esta: todas as pessoas, das diferentes crenças e valores, reunidas em torno dos dois meninos mortos, chorando em solidariedade à dor de Dona Joana. 
Vemos assim que há um conflito religioso entre a fé evangélica pentecostal com seu exclusivismo e intolerância diante das outras religiões, principalmente as de matriz africana e as práticas profanas, mundanas e sexuais, como o carnaval. Por sua vez, a própria Dona Joana recorre aos búzios para ser informada do paradeiro de seus filhos. Diante da morte trágica e violenta dos meninos, as diferenças religiosas ficam relativizadas.

Nos três filmes, temos o elemento cômico e o elemento trágico. Nos três, vemos as pessoas envolvidas organizando suas crenças à sua maneira, independentes da instituição religiosa. Nos três, o conflito, a violência e a morte se fazem presentes.

\section{c. Linha de passe: o conflito da falta de esperança e a intolerân- cia aos invisíveis}

Linha de passe (Walter Salles; Daniela Thomas, BRA, 2008) foi dirigido por Walter Salles e Daniela Thomas e lançado em 2008. ${ }^{4}$ A linha de passe no futebol é o momento e local certo onde um jogador precisa passar a bola ao outro, possibilitando, assim, o cumprimento da meta, o gol. Exatamente sobre isso trata o filme que leva este nome: a linha de passe na vida de pessoas na periferia do mundo na busca pela sobrevivência.

O filme é caracterizado por um realismo que, por vezes, dá a impressão de se tratar de um filme reportagem. Ele conta a história de quatro irmãos e uma mãe, que vivem na Cidade Líder, periferia da metrópole São Paulo. São todos torcedores fanáticos do Corinthians (Sport Club Corinthians Paulista). Com a ausência do pai, precisam lutar por seus sonhos. Um deles, Dario (Vinícius de Oliveira), percebe em seu talento como jogador de futebol a esperança de uma vida melhor. Aos 18 anos de idade, vê a ideia cada vez mais distante, já que jogadores são descobertos mais jovens. Reginaldo (Kaique de Jesus Santos), o caçula, procura seu pai obsessivamente. Dinho (José Geraldo Rodrigues) converteu-se a uma igreja evangélica pentecostal, abandonando uma vida mundana de bebedeira. Dênis (João Baldasserini), pai de um menino com uma moça com quem já não está vivendo junto, enfrenta dificuldades em se manter financeiramente como motoboy e pagar a pensão ao filho.

4 O filme foi aplaudido por nove minutos durante o Festival de Cannes, além de ganhar o prêmio de melhor atriz pela atuação de Sandra Corveloni. 
Todos, aparentemente, são filhos de pais diferentes, tendo sido criados por Cleuza (Sandra Corveloni), sua mãe, que trabalha como empregada doméstica e está mais uma vez grávida, de outro homem. Cleuza luta, sozinha, sendo pai e mãe, ao mesmo tempo, para sustentar seus filhos, manter a casa precária na periferia, com a pia sempre entupida, reproduzindo uma realidade muito comum no Brasil de hoje. Mesmo grávida, fuma e bebe para aliviar a tensão. Ela também é torcedora do Corinthians. Em algumas cenas, ela está no jogo torcendo e rezando por seu time do coração.

O conflito aqui não é de uma religião com outra, nem da religião com determinada situação de vida, ideologia, movimento. Não há uma religião que perpassa todo o enredo do filme, como nos exemplos anteriores. O futebol seria aqui o elemento mais religioso que emoldura todo o drama.

O conflito e a intolerância em Linha de passe é a marginalidade social, a invisibilidade social e a falta de perspectiva. O conflito é com a linha de passe da vida real, que parece nunca se concretizar. O conflito é com a falta de esperança e a impossibilidade humana de vir a ter - vir a ser - uma vida digna em uma cidade e em uma sociedade que invisibiliza a maioria dos seus cidadãos. As possíveis "linhas de passe" são: conseguir jogar futebol em um clube de destaque e assim ascender socialmente, sonho de milhares de jovens no Brasil (Dario); conseguir a prosperidade por meio da fé e da conversão espiritual, à espera de um milagre que não acontece (Dinho); conseguir um trabalho ou atividade - que seja na criminalidade, no roubo - com um salário que permita viver uma vida minimamente decente e sustentar o filho pequeno (Dênis); na busca pelo pai, motorista de ônibus (Reginaldo); conseguir garantir a sobrevivência de seus filhos - encontrar a linha de passe para eles - e torcer (no grande jogo da vida, contar com a sorte) para que sobrevivam às atrocidades da grande cidade (Cleuza).

Praticamente todas as possibilidades dão errado. Dario não consegue o destaque necessário para uma vaga como jogador de futebol; Dinho volta a beber, perde o emprego, parece perder a fé; Dênis rouba e, na fuga, sequestra alguém; Cleuza sente as dores de parto de mais um filho que está chegando; Reginaldo rouba um ônibus e sai, sem rumo, dirigindo pela cidade. Talvez essa seja a possibilidade mais plausível, mesmo que absurda. O único lugar onde parece que uma linha de passe é de fato efetiva é assistindo ao time do coração, amado e idolatrado como uma religião, o Corinthians.

Significativos para este estudo são os momentos de Dinho, na igreja. Trata-se de uma das tantas pequenas igrejas de periferia, evangélica pente- 
costal, com uma clara teologia da prosperidade e da cura. As poucas pessoas que frequentam os cultos mostram em seus rostos as marcas da pobreza e das dificuldades cotidianas. Numas das primeiras cenas, a comunidade reunida canta com devoção o hino que diz "você é importante para Deus". Outra cena muito ilustrativa para a temática do filme é a que mostra a tentativa de cura de uma senhora paraplégica. Apesar de toda oração e bênção proferida, a mulher não volta a andar. Duas tentativas, uma inclusive no dia do seu batismo, no rio, fracassam. Os únicos que parecem se dar conta da impossibilidade são Dinho e a própria mulher.

Linha de passe, 44 anos depois de Deus e o Diabo na Terra do Sol, parece colocar seus protagonistas no mesmo lugar - na falta de perspectiva. A diferença aqui, porém, é que nem a religião, nem a marginalidade, nem o futebol parecem de fato apontar uma saída, mesmo que momentânea. Linha de passe encerra sem esperança. Em Linha de passe, religião e conflito se resumem em uma palavra: lamento. Significativo, nesse sentido, é quando Dinho, na metade do filme, lê para uma irmã na fé, Dona Rosa, versículo do que parece o Salmo 13 e o Salmo 102:

Até quando se esquecerá de mim senhor? Enquanto lê para sua irmã na fé cristã, o foco narrativo mantém o áudio no discurso proferido por Dinho e focaliza em outra cena o rosto sofrido de sua mãe Cleuza [...] que espera em pé, num ponto lotado de pessoas, por um ônibus que a leve do centro da cidade de volta para Cidade Líder - bairro na zona leste da capital paulista - onde ela vive com quatro filhos e espera pelo próximo, grávida que está de provavelmente oito meses. Dinho segue na leitura: Até quando esconderás de mim o teu rosto? Outro close no rosto de Cleuza, que apesar da aparência envelhecida não deve ter mais de 40 anos; ela fuma cigarros em profusão, como se esses pudessem dar alívio para sua tensão na repetição de um dia estafante de trabalho. E Dinho prossegue: Porque meus dias se consomem como a fumaça, e os meus ossos ardem como lenha. Novo enfoque no rosto da mãe, seu olhar sério e compenetrado nos dá a entender que ela parece mesmo sentir dor e cansaço. Seja no trabalho em "casa de família", seja em sua casa na periferia, Cleuza é apresentada, inúmeras vezes, fumando cigarros e/ou bebendo cerveja. Isso nos remete à voz de seu filho, como se suas palavras fossem os dias de Cleuza, queimados juntamente com aquela fumaça ou consumidos num único gole. Dinho prossegue na leitura e novo corte na cena nos mostra Dario (Vinícius de Oliveira) sentado no sofá de casa, diante da televisão, com a expressão facial de desânimo após ficar de fora em mais uma "peneira", como é comumente conhecida a pré-seleção no futebol amador. Dinho prega: Meu coração está ferido e seco como erva, por isso me esqueço de comer o pão. Em seguida, após 
apresentar os protagonistas do filme a câmera aponta para o céu num dia nublado e desce devagar nos dando uma imagem panorâmica, porém não menos acinzentada, da cidade de São Paulo, metrópole de pedra e concreto que nos parece impenetrável vista de cima. A cidade também nos parece ser o personagem principal do filme, pois é com a sua imagem que Dinho encerra a leitura do salmo: Os meus dias são como a sombra que declina e como a erva me vou secando. [...] Novo corte brusco na cena e agora é Dênis, outro filho, quem aparece dirigindo apressadamente sua moto pelas principais avenidas da cidade (LIMA; SILVA, 2009).

\section{Considerações finais}

Segundo Ruben Alves "A religião é a proclamação da prioridade axiológica do coração sobre os fatos brutos da realidade. Ela é a recusa, por parte do ser humano, de ser digerido e assimilado ao mundo que o cerca, em nome de uma visão, de uma paixão, de um amor" (ALVES, 1988, p. 19). De fato, não por acaso que religião é algo tão fundamental e constitutiva no Brasil, em um contexto marcado por tamanho conflito, injustiça, violência e falta de perspectiva. Nesse contexto, os filmes analisados apresentam uma religião vivida que busca dar conta de uma realidade ou que contribui para aliviar ou para aprofundar o conflito e a violência.

$\mathrm{O}$ que caracteriza essa religião vivida que contracena com esse contexto de conflito e violência? Certamente, é uma religião que está em grande sintonia com aquilo que Schultz chama de nebulosa religiosa. É uma religião que não despreza a presença de Deus, mesmo quando Deus parece estar mais no futebol que na igreja, como no caso de Linha de passe. Há intimidade com Deus e com o divino, como se vê na relação de João Grilo com Maria e Jesus, no céu. Deus, suas potestades, o divino não se restringem às igrejas. Estão nos terreiros, nas escadarias da igreja, na cura de pessoas e animais, em pessoas e lugares. Se Deus está presente, o diabo está também (Schultz), como se percebe em Deus e o Diabo na Terra do Sol. A mesma pessoa, Manoel, transita de penitente a cangaceiro, com grande facilidade. Também em $O$ Auto da Compadecida temos destaque especial para o diabo, conhecedor das personalidades e seus dilemas. O mal está muito presente na própria igreja institucional, intolerante e aliada ao poder, como se vê em O pagador de promessas e na obra de Glauber Rocha. O mal está relacionado ao poder político, como no coronelismo, na ditadura militar,

na violência contra as crianças, em Ó pai ó, ou na periferia do mundo, na falta de perspectiva, em Linha de passe. 
Nessa religião o mundo visível, a realidade dura e cruel, que, muitas vezes, é encarada como sina, o destino, a necessidade, o preceito divino (Manuel, Zé do Burro, Severino, os Frei Tito e Frei Betto, Dinho e Cleuza), e o mundo invisível, o mundo dos mortos, o céu ou a esfera dos Orixás estão em permanente interação. Em $O$ Auto da Compadecida, vai-se de um desses lugares para outro com grande facilidade. A incorporação, o êxtase, a manifestação de cura mostram a relação entre as dimensões humana e divina, como no caso do jogo de búzios, no caso do beato Sebastião que se assume como profeta, na expectativa de cura no culto evangélico.

A religião nesses filmes é uma religião híbrida, bricolada, rizomática, indiferente às dogmáticas e liturgias institucionais (SCHULTZ, 2008, 50). Trata-se de uma religiosidade misturada, sincrética, ambígua, como no caso de Zé do Burro e na trama de O Auto da Compadecida. Animais - burro e cachorro - são tão importantes quanto pessoas na economia divina. Inclusive Orixás e fé evangélica se aproximam se a ameaça à vida bate à porta, como em Ó pai ó. Ressignificações são livremente criadas, como as profecias e interpretações messiânicas em Deus e o Diabo na Terra do Sol: saques e pilhagem, sacrifício de crianças combinam com a esperança apocalíptica de um sertão que vai virar mar e de chuva de ouro.

Sacrifícios, a busca pela perfeição e o ideal de santidade também estão presentes nessa nebulosa religiosa brasileira. Vemos sacrifício no movimento messiânico de Dom Sebastião, no pagador de promessas, quase reproduzindo o sacrifício de Cristo, na vida abstemia (droga e sexo) de Dona Joana e de Dinho, na tortura a que se deixam submeter os frades católicos no engajamento sociopolítico, a luta de Cleuza para sustentar sua família. Santos são menos os padres e os bispos e mais os beatos, os vaqueiros, os cangaceiros, João Grilo, a mãe de santo.

Uma pergunta que se coloca é em que medida essa religião vivida presente nos filmes analisados é resultado do contexto conflitivo, violento e ambíguo do Brasil e, uma segunda, em que medida essa religião contribui - ou não - para a dignidade humana e a transformação social, nesse contexto. No que se refere à primeira pergunta, tudo leva a crer que sim a religião vivida, como uma expressão mais próxima da vida cotidiana e comum, carrega de forma mais crua e explícita a realidade conflitiva e violenta endêmica do contexto. Quanto à sua influência para a preservação da dignidade humana e a transformação social, a religião vivida se não busca a superação da violência e suas forças geradores, procura aplacá-las e aponta para caminhos, subterfúgios de sobrevivência, mesmo que, 
por vezes, de forma agressiva ou até violenta. Religião aqui seria, no mínimo, um modo de dissimulação, enquanto formas efetivas de transformação, dentro e fora do campo religioso, não se colocam à disposição.

Quem dissimula geralmente está numa posição não-privilegiada, e a estrutura de dissimulação acaba se tornando uma estratégia de sobrevivência, e não exatamente uma vivência. [...] no contexto do imaginário religioso parece inevitável considerar essa dissimulação [...] não apenas como uma forma de resistência à imposição de religiões hegemônicas, mas, sobretudo, como uma espécie de resistência passiva do povo fiel contra os discursos dualistas e exclusivistas das religiões (SCHULTZ, 2008, 56).

Ou seja, as questões que surgem a partir desta reflexão, principalmente no que se refere à hermenêutica da religião vivida com suas implicâncias e consequências para a própria Teologia Prática, levam a uma questão chave: o papel da Teologia Prática nesse contexto de conflito e intolerância. Ou seja, em que medida a prática da Igreja, em especial o culto, a liturgia e a pregação, mas também a catequese, a diaconia e a missão, levam em conta os conflitos e intolerâncias explicitadas na cultura pop, no caso, nos filmes? Em que medida análises como esta abrem espaço para compreensões e vivências religiosas que extrapolam os códigos dogmáticos da orto-práxis eclesiástica? Em que medida essa religião vivida trazida através do cinema poderia despertar uma reflexão, um novo olhar, uma autocrítica social, cultural, política e religiosa? Quais as possibilidades de se repensar a Igreja e sua práxis no contexto brasileiro a partir da religião vivida aqui esboçada? Estudos como estes certamente podem dar uma grande contribuição para a Teologia Prática e a própria Teologia, como um todo.

\section{Referências}

ADAM, Júlio Cézar. Romaria da Terra: Brasiliens Landkämpfer auf der Suche nach Lebensräumen, 1. ed. Stuttgart: Kohlhammer, 2005.

ALVES, Rubem. O enigma da religião. 4. ed. Campinas: Papirus, 1988.

BALTAZAR B. JÚNIOR, Edilson; BARREIRA, Ruama de Almeida. O vaqueiro, o penitente e o cangaceiro: messianismo no filme "Deus e o diabo na terra do sol" de Glauber Rocha. História, imagem e narrativas, n. 16, abr. 2013, p. 1-16.

BOFF, Leonardo. Depois de $\mathbf{5 0 0}$ anos que Brasil queremos? 2. ed. Petrópolis: Vozes, 2000. CANASSA, Rosângela D. Análise do filme Linha de passe: a nossa sociedade demanda um novo olhar sobre a cultura e a mulher. Disponível em: https://identidadediversa.wordpress. 
$\mathrm{com} /$ projetos-coletivos/analise-do-filme-linha-de-passe-a-nossa-sociedade-demanda-um-novo-olhar-sobre-a-cultura-e-a-mulher/ Acesso em: 14 jun. 2016.

CUNHA, Magali Nascimento. Deus e o Diabo na terra Brasil. Disponível em http://www. ihu.unisinos.br/noticias/552888-deus-e-o-diabo-na-terra-brasil. Acesso em: 14 jun. 2016b.

CUNHA, Magali Nascimento. Religião no noticiário: marcas de um imaginário exclusivista no jornalismo brasileiro. Revista da Associação Nacional dos Programas de Pós-Graduação em Comunicação | E-compós. Brasília, v. 19, n. 1, jan./abr. 2016.

DAMATTA, Roberto. Carnavais, malandros e heróis: para uma sociologia do dilema brasileiro, 6. Aufl. Rio de Janeiro: Rocco, 1997.

DAMATTA, Roberto. O que é o Brasil. Rio de Janeiro: Rocco, 2004.

GANZEVOORT, R. Ruard. Encruzilhadas do caminho no rastro do sagrado. Estudos Teológicos. São Leopoldo, v. 49, n. 2, jul./dez., 2009, p. 317-343.

LIMA, Lilian Victorino Félix de; SILVA, Luciana Meire da. Linha de passe: driblando as dificuldades no jogo da vida urbana. Baleia na Rede, v. 1, n. 6, Ano VI, dez. 2009, p. 33-46.

RIBEIRO, Darcy. O povo brasileiro: a formação e o sentido do Brasil, 2. Aufl. São Paulo: Companhia das Letras, 1995.

SANTOS, Joe Marçal Gonçalves dos. Cinema e teologia: por que tratar de cinema numa teologia da cidade? In: ZWETSCH, Roberto E. (Org.). Cenários urbanos: realidade e esperança. Desafios às comunidades cristãs. São Leopoldo: Sinodal, EST, 2014, p. 241-255.

SCHULTZ, Adilson. Estrutura teológica do imaginário religioso brasileiro. In: BOBSIN, Oneide, et allii (Org.). Uma religião chamada Brasil: Estudos sobre religião e contexto brasileiro. São Leopoldo: Faculdades EST/Oikos, 2008, p. 27-60.

SOUZA MARTINS, José. Álibis e disfarces da descrença - a religiosidade intersticial no Brasil contemporâneo. In: REBLIN, Iuri; SINNER, Rudolf von (Org.). Religião e sociedade: desafios contemporâneos. São Leopoldo: EST/Sinodal, 2012, p. 291-299.

STEIL, Carlos Aberto. O sertão das romarias: um estudo antropológico sobre o Santuário de Bom Jesus da Lapa - Bahia. Petrópolis: Vozes, 1996.

VELASCO, Breno Ricardo da Silva; PEREIRA, Edvaldo Santos; BARBOSA DA COSTA, Regina. Batismo de sangue: resistência da palavra contra a ditadura no Brasil. Disponível em: http://periodicos.ufsm.br/LA/article/viewFile/11541/7001. Acesso em 14/06/2016.

Submetido em: 9-7-2016

Aceito em: 27-7-2017 